\title{
Metalinguistic Awareness and Reading Acquisition in the Spanish Language
}

\author{
Juan E. Jiménez González and María del Rosario Ortiz González \\ University of La Laguna
}

This research was designed to establish the importance of phonological awareness and print awareness in lcarning to read Spanish. A sample of 136 preliterate Spanish children (70 boys and 66 girls) whose ages ranged from 5.1 to 6.6 years (average age 5.6 years) participated in the study. The results, using path analysis, from this longitudinal study support the existence of a relationship between phonological awareness and reading. Moreover, the findings of this study reveal the importance of syllabic awareness, at least in Spanish, in the development of other levels of phonological awareness and in its early relation with reading. The results also confirm the existence of a relationship between print awareness and reading comprehension.

Key words: metalinguistic awareness, path analysis, reading acquisition, correspondence between graphemes and phonemes, phonological awareness, print awareness

El objetivo de esta investigación era estudiar la importancia que tiene el conocimiento fonológico y el conocimiento general acerca del lenguaje escrito, en el aprendizaje de la lectura en lengua española. Por ello, se seleccionó una muestra de 136 niños españoles prelectores (70 niños y 66 niñas) con edades comprendidas entre 5.1 y 6.6 años. Los resultados obtenidos a través del estudio longitudinal muestran la existencia de una relación entre conocimiento fonológico y aprendizaje de la lectura y entre conocimiento general del lenguaje escrito y comprensión lectora. Además, los resultados también muestran la importancia que tiene el conocimiento silábico en la adquisición temprana de la lectura y en el desarro:lo de otros niveles de conocimiento fonológico, al menos en español.

Palabras clave: conocimiento meta-lingüistico, análisis de vias, adquisición de la lectura, correspondencia grafema-fonema, conocimiento fonológico, conocimiento del lenguaje escrito

This research was funded by a grant from Vicerrectorado de Investigación, Universidad de La Laguna, Tenerife, Canary Islands. We wish to thank Juan Andrés Cabrera for his help with the data analyses.

Correspondence concerning this article should be addressed to Juan E. Jiménez González, Departamento de Psicología Evolutiva y de la Educación. Universidad de La Laguna. Campus de Guajara. 38200 Islas Canarias (Spain). E-mail: ejimenez@ull.es; Fax: $922-317461$ 
Many authors have suggested that metalinguistic development is related to a more general change in information-processing capability that occurs during midchildhood, that is, the development of metacognitive control over information-processing systems (Hakes, 1980; Tunmer \& Bowey, 1984; Tunmer \& Herriman, 1984). The more general term metacognition was initially reserved for conscious knowledge (Flavell \& Wellman, 1977), but it was extended to include executive control (Brown, 1980). The results of several studies suggest that during mid-childhood, children become increasingly aware of how they can control their intellectual processes in a wide range of situations and tasks, including those requiring metalinguistic skills (for a review, see Flavell, 1985). This linkage of metalinguistic development to metacognitive development may help to explain why the ability to treat language as an object of thought is not an attomatic consequence of language acquisition. Unlike normal language operations, which involve automatic processing, metalinguistic operations require control processing. Thus, for example, phonological awareness and general awareness are considered abilities which emerge in the early stages of development and reflect the development of analyzed knowledge and cognitive control that appears during pre-school ages.

An important implication of the development of metalinguistic awareness concerns the problem of learning to read. Children learning to read appear to progress through three major stages: (1) realizing that print conveys meaning in much the same way as speech (i.c., analyzed knowledge), (2) attending to printed features (e.g., letters, letter combinations, spaces between words, capitalization, punctuation) of linguistic elements, and interpreting them (i.e., involves both analyzed knowledge and control), and (3) incorporating attention to forms with the goal of extracting meaning - i.e., an achievement of cognitive control (Bialystok \& Bouchard, 1985).

Models of reading acquisition involve phonological awareness as an influential factor (e.g., Goswami \& Bryant, 1990; Lomax \& McGee, 1987; Lundberg \& Høien, 1991). Phonological awareness can be defined as the ability to rellect on and manipulate the sublexical linguistic units of specch. Phonological awareness is an ability that does not constitute a homogeneous entity, but rather is expressed in terms of awareness of different linguistic units. For instance, Treiman (1991) interpreted phonological awareness as awareness of any phonological unit, be it syllables, onsets, thymes, or phonemes. Taking into account studies which have shown that in the Spanish language, sublexical units such as syllables are processed by children during reading (Jiménez, Guzmán, \& Artiles, 1997), then syllabic awareness should be uscful for reading transparent orthography (i.e., the correspondence between graphemes and phonemes). Moreover, the Spanish language has clearly defined syllable boundaries. Therefore, some studies conducted in the Spanish language found that syllabic awareness is a good predictor of future reading ability
(Carrillo, Romero, \& Sánchez-Meca, 1992), although more research is necessary to test whether or not syllabic awareness is a precondition of learning to read in Spanish.

Several studies have also found that sensitivity to rhyme in preschool children is a good predictor of future reading ability (Bradley \& Bryant, 1985; Ellis \& Large, 1987; Lundberg \& Høien, 1991; Lundberg, Olofsson, \& Wall, 1980; Share, Jorm, MacLean, \& Matthews, 1984). Theoretical models have been proposed in which intrasyllabic awareness contributes directly to reading, which is independent of the connection between reading and phonemic awareness (Bryant, Maclean, Bradley, \& Crossland, 1990). The assumption underlying these findings is that children who are able to categorize words based on rhyme or onset, when they are learning to read, would realize that words with similar orthographical patterns are pronounced similarly. Consequently, they could read new words by making analogies with known words belonging to the same category (e.g., right, light, might, sight, ctc.).

With regard to phonemic awareness, Ball (1993) suggested that the directionality of phonemic awareness and reading depend on experience with the alphabetic code; that is, before learning to read, phonemic awareness is a causal variable of reading performance. After experience, the relationship between these variables is bi-directional or reciprocal. This hypothesis, based on reciprocal effects, has received empirical support in studies where learning to read in alphabetic systems facilitated phonemic awareness (Ehri \& Wilce, 1980; Morais, Cary, Alegría, \& Beterlson, 1979; Read, Zhang, Nie, \& Ding, 1986; Wimmer, Landerl, Linortner, \& Hummer, 1991).

However, the Spanish language presents a much higher degree of onthographic transparency than English does because in English, there are multiple ways to pronounce certain graphemes. In Spanish, there are exceptions with some letters (i.e., $c, g$, and $r$ ), but these can be predicted from contextdependent graphophonological rules. For this reason, decoding in Spanish does not represent a problem and phonemic awareness can be helpful in word decoding. However, we do not know whether all the levels of phonological awareness in a transparent orthography would be equally important to reading acquisition. For example, onset-rhyme awareness may be less relevant in Spanish for two reasons: (a) there is a direct correspondence between graphemes and phonemes in Spanish, and (b) rimes are particularly salient in the monosyllables. Spanish has fewer one-syllable words with rhymes than English. Consequently, the relative influence of different forms of phonological awareness (e.g., intrasyllabic or phonemic awareness) to explain reading acquisition may depend on orthographical systems.

Moreover, a relationship between general awareness and reading has been shown (Lomax \& McGee, 1987; Lundberg \& Høien, 1991). Children who are learning to read have some idea of what reading is all about. General awareness has been considered an hetcrogeneous ability and includes three 
different aspects: (a) recognizing literacy behavior, (b) understanding literacy functions, and (c) print awareness. Before learning to read, children possess some awareness of the reading goals and of the main conventions regarding the manipulation of the written word, such as directionality. They are also aware of the characteristics of some letters, and are able to name some of these. And, they can tell the difference between a word, a letter, and a written number (Gombert, 1992, p. 152). Print awareness is the general awareness component which has received greater empirical support (e.g., Francis, 1973; Ganopole, 1987; Mickish, 1974). Research has revealed that this awareness showed a stronger relationship with reading comprehension performance than with the identification of letters at the end of second grade. Moreover, it is the only pre-reading variable reported that is related to reading comprehension (Tunmer, Herriman, \& Nesdale, 1988).

All these variables that were analyzed independently could be related. Lundberg and Høien (1991, p. 77) proposed a model in which reading acquisition emerges from two separate but related ontogenetic roots,

[...] one being critical to word decoding and the other related to the comprehension aspect of reading. Print awareness may be an integral part of the second developmental strand, which also includes book-handling skills, experience of story-telling, exposure to decontextualized discourse, formal language, and so on. These dimensions of development are assumed to be projected more onto the aspects of reading concerned with interpretational processes at the text level. The factor behind word recognition or decoding, however, has rather to do with phonological awareness than print awareness.

Drawing from this conceptual model, and using structural equation modeling, this study tests several hypotheses regarding the importance of phonological awareness and print awareness in learning to read Spanish.

The current model guiding this research includes four main components: (a) print awareness, (b) phonological awareness (with three levels: syllabic awareness, intrasyllabic awareness, and phonemic awareness), (c) decoding (operationalized by word reading and pseudoword reading), and (d) reading comprehension.

A key assumption of the model here presented is that the levels of phonological awareness (i.e., syllabic, intra-syllabic, and phonemic awareness) have a stronger relationship with decoding (i.e., word reading and pseudoword reading) but not with reading comprehension, whereas print awareness is related to reading comprehension but not to decoding.

The first component of the model is print awareness, which was included in the model as a variable related to reading comprehension. The prediction for print awareness is that it maintains a relationship with reading comprehension (i.e., the concepts of the features of printed materials that the children have before learning to read would be causally linked with reading comprehension). In addition, we expect that reading instruction would facilitate the development of this metalinguistic domain, which also influences reading comprehension.

The second component is phonological awareness. The first level of phonological awareness (syllabic awareness) was included in the model because it may have more influence than other types of phonological awareness on decoding performance in a transparent orthography (i.e., Spanish). It was contended that the relationship between syllabic awareness and reading would depend on whether syllabic awareness is assessed before or after learning to read. Before learning to read, syllabic awareness would have a causal link with future decoding ability because syllabic awareness is necessary for learning the correspondence between graphemes and phonemes. But once children receive reading instruction, syllabic awareness would be a way to develop the awareness of intra-syllabic units (i.e., onsetrhyme). Therefore, it was suggested that the relationship between syllabic awareness and decoding would be influenced by phonemic or intra-syllabic awareness.

The second level of phonological awareness is intrasyllabic awareness (i.e., onset-rhyme). Intra-syllabic awareness was included in the statistical model as an ability that would be influenced by syllabic awareness. In addition, it is believed that this ability, assessed after leaming to read, would make a direct contribution to decoding, independently of the contribution from phonemic awareness. Moreover, this proposal allows us to test the ditect influence of intrasyllabic awareness on decoding.

The third level of phonological awareness was phonemic awareness, which was included as another component in the statistical model. It was intended to test whether phonemic awareness in children who have learned to read has a causal link with reading, specifically with the decoding of pseudowords.

Two other components were included in the model (i.e., decoding - word reading and pseudoword reading-, and reading comprehension). Pseudoword reading was introduced in the model before word reading because it is considered to be a more powerful predictor to account for the variance in word reading (Wagner \& Torgesen, 1987). Word reading was iflcluded in the model as a variable that is influenced by pseudoword reading. Finally, reading comprehension was the component that is influenced by the knowledge that children have concerning written language features. This influence would exist both before and after reading instruction.

\section{Method}

\section{Participants}

A sample of 136 preliterate Spanish children ( 70 boys and 66 girls) whose ages ranged from 5.1 to 6.6 years (average age 5.6 years) participated in the study. The children came 
from rural $(n=37)$, urban $(n=48)$, and suburban areas $(n=$ 51). Two years later, at the end of the study, the mean IQ was $117.1(S D=15.8)$, as measured by the Lorge-Thorndike Intelligence Test (Lorge \& Thorndike, 1954). These children learned to read by code-oriented instruction, and every grapheme-phoneme correspondence was explicitly taught in first grade. Reading instruction starts with simple (c.g., $m, p$, and $t$ ) and moves to more complex correspondences (e.g., $c$. $g$, and $r$ ). This is the most common approach to reading instruction in Spanish schools.

\section{Materials and Procedure}

To test our hypotheses, three measures of print awareness were taken on three different occasions during the readinglearning process: at the beginning of kindergarten (PAI), at the end of kindergarten (PA2), and at the end of the first grade (PA3). Sytlabic awareness was also assessed at the beginning of kindergarten (SYL1), at the end of kindergarten (SYL2), and at the end of the first grade (SYL3). Moreover, measures were taken of intra-syllabic awareness (INTRA), phoneme awareness (PHON), word reading (WR), pseudoword reading (PSWR), and reading comprehension (RC) at the end of the first grade, after one year of instruction in the rules of correspondence between graphemes and phonemes. All participating students were tested individually at the school site during class time.

Print Awareness. Print awareness ability was assessed by the Spanish "Prueba de Conocimientos sobre el Lenguaje Escrito" (CLE, [Written Language Knowledge Test]; Ortiz \& Jiménez, 1993). Only the items from this test that make up the factors connected with print awareness were used. These items were: (1) differentiation between numbers and letters, (2) word recognition, (3) localization of the first letter and word of the sentence, (4) localization of the last letter and word of the sentence, and (5) localization of the first and last line of text.

1. Differentiation between numbers and letters. This task consisted of six trials. The items in each trial consisted of numbers, letters, and visual forms. The children were shown each item and asked whether it was a letter or a number.

2. Word recognition. This task consisted of two trials. Each trial consisted of letters, syllables, numbers, and words. The children's task was to identify the stimuli that represented the words.

3. Localization of the first letter and word of the sentence. This task consisted of four trials. Each trial contained a written sentence and the children were asked to identify the first letter and word in the sentence.

4. Localization of the last lenter and word of the sentence. This task consisted of three trials. The children were asked to identify the last letter and word of the sentence.

5. Localization of the first and last line of text. This task consisted of two trials. Each trial contained a short text and the children were required to identify the first and the last line of text. For most of the items, there was more than one correct response. In order to even the item weights, the number of correct responses to each item was multiplied by a constant (which varied depending on the number of possible correct responses and the number of alternatives for the item), so that the maximum score for each item was 10. The total score was obtained by adding the scores of all the ilcms.

Syllabic Awareness. Various tasks from the Spanish "Prueba de Segmentación Lingüística" (PSL, [Linguistic Segnentation Testl; Jiménez \& Ortiz, 1995) were used to assess the children's ability to divide and manipulate the syllabic components of words. The following tasks were employed: (1) isolitting syllables, (2) syllabic synthesis, (3) syllabic segmentation, and (4) syllable deletion.

1. Isolating syllables. The task for isolating syllables consisted of discovering, in a series of drawings, the names of those objects which began or ended with a certain syllable pronounced by the examiner (e.g., identifying the objects which began or ended with $\mid$ sal: a picture of a sack [saco], a drum [tambor], a ship [barco ], a moon [luna $]$ ). This task consisted of three trials.

2. Syllabic synthesis. This syllabic synthesis task assessed the skill in recognizing and pronouncing words that had previously been divided into syllables. All stimuli were registered on a tape recorder in order to control the time interval (three seconds) between the syllables of the words. The words had two or three syllables. In the examples, the examiner explained the rules of the game, which consisted in discovering words (c.g., bi-go--tc|moustachel) "What is this word?" "The word is bigote" [moustache]). This task consisted of five trials.

3. Syllabic segmentation. The children counted the syllables of orally presented wotds and were allowed to use aids such as fingers. Each word was presented individually and the examincr asked the children how many parts the word had (e.g., "Listen: caballo [horse]. How many parts does it have?"). This task consisted of five trials.

4. Syllable deletion. The syllable deletion task consisted of 24 trials. For each trial, a picture was presented and the children named it, however, omitting the syllable previously pronounced by the examiner. This syllable could be either at the beginning, in the middle, or at the end of the word (e.g., /cal in boca [mouth]). The words had either two or three syllables. The total score was obtained by adding the number of correct responses to each task.

Intra-syllabic Awareness. Two oddity tasks were used to measure this variable. Task $A$ assessed rhyme awareness and Task B, onset awareness. The oddity tasks were carried out employing as models those used by Bowey and Francis (1991); however, with the difference that only 2-syllable words were used, owing to the difliculty of linding sufficient one-syllable words in the Spanish language appropriate for this task. Each task had two examples and eight trials. The items consisted of groups of three 2 -syllable words. In the 
rhyme awareness task (A), the children's attention was focused on the final syllablc of the word and they were asked which word in the group had a different-sounding enditig (e.g., bucal-moral-vejez, [oral-moral-old age]). In the onset awareness task (B), the examiner pronounced each trio and the children had to identify the word that was different because it did not begin with the same consonant segments (e.g., craso-credo-flujo [crass-creed-flow]). The examiner repeated each trio as many times as was necessary for the children to recall it. The total score was the sum of the correct responses of tasks $\mathrm{A}$ and $\mathrm{B}$.

Phonemic Awareness. The design of the phonemic awareness task was also based on the study by Bowey and Francis (1991). Two oddity tasks were used. Task A assessed initial-phoneme awareness of the word and Task $B$, secondinitial-phoneme awareness. Each task had two examples and 8 trials. The items consisted of groups of three 2-syllable words. In the first four trials, the first syllable of the words was stressed, in the other four, the final syllable. In Task A, each group was pronounced by the examiner and the children were asked to identify which word was different because it did not begin with the same phoneme (e.g., grumo-fragilgreña [lump-fragile-matted hair]). In Task B, the children had to identify the word that contained a different secondinitial phoneme (e.g., gloria-grana-greca [gloria-scarletborder[). The total score was the sum of the correct responses of tasks $A$ and $B$.

Reading Measures. At the end of the first grade, reading comprehension and decoding of words and pseudowords were measured.

1. Reading comprehension. The "Subtest de Comprensión Lectora, Nivel II" [The Reading Comprehension Subtest,
Level II ] from the Spanish "Test de Análisis de Lectura y Escritura" ([Reading and Writing Analysis Test]; Toro \& Cervera, 1980) was selected to assess reading comprehension. Subjects provided answers to 10 questions about a text, which contained 69 words, immediately after reading it. The total score was the sum of the correct responses.

2. Word and pseudoword reading. Reading (or "decoding") was evaluated using the Spanish "Prueba de Lectura" ([Reading Test]; Jiménez, Guzmán, \& Ortiz, 1991). The child was required to read words and pseudowords aloud. The number of errors made when reading 80 words and pseudowords was counted.

\section{Statistical Analyses}

In order to test the proposed theoretical model, path analysis was carried out using an EQS statistical program (Bentler, 1989). This statistical technique is used to test a theoretical model in one or more groups, and also to contrast different models in just one group (for a description, see Byrne, 1994). In the current research, we made use of this technique to see whether the theoretical model postulated a priori would fit the data. If a proposed model does not fit the data, then the theory must be revised in order to improve the model's fit (e.g., León \& Hernández, 1998). The hypothesized model to be tested, shown in Figure 1, posited that levels of phonological awareness (i.e., syllabic, intrasyllabic, and phonemic awareness) would have a relationship with decoding but not with reading comprehension, whereas print awareness would be related to reading comprehension but not to decoding.

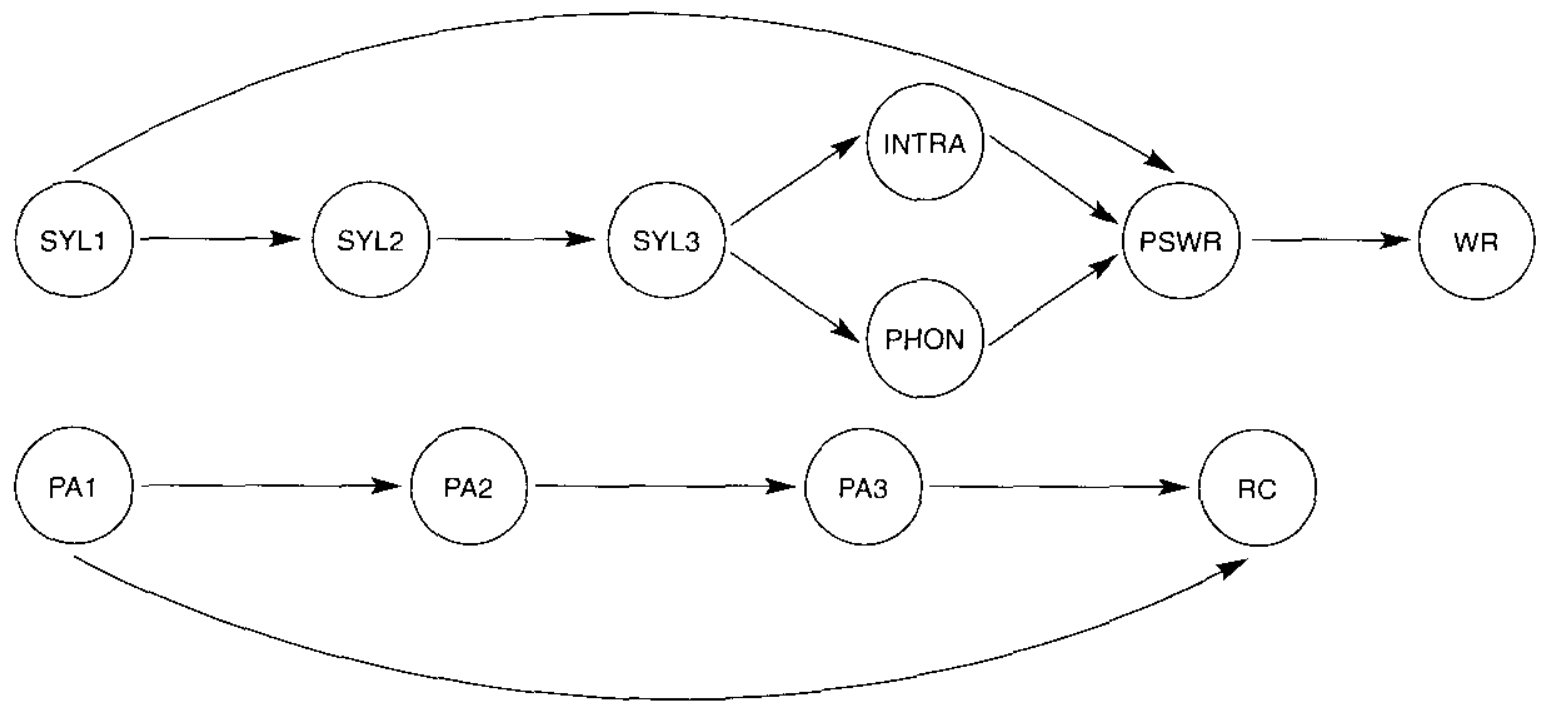

Figure l. The hypothesized model to be tested. SYL = syllabic awareness (measured at three different times: at the beginning of Kindergarten [SYLI], at the end of Kindergarten [SYL2], and at the end of first grade [SYL3]; INTRA = intra-syllabic awareness; PHON = phonemic awareness; PSWR = pseudoword reading; $W R=$ word reading; PA = print awareness (mteasured at three different times: at the beginning of Kindergarten [PA1], at the end of Kindergarten [PA2], and at the end of first grade [PA3]); $\mathrm{RC}=$ reading comprehension. 
Several other specific hypotheses were tested regarding the importance of phonological awareness and print awarencss in learning to read Spanish:

(1) The concepts of printed matcrial features (PA 1) held by students before learning to read would predict their reading comprehension ( $\mathrm{RC}$ ).

(2) There is a relationship between syllabic awareness, when assessed before learning to read (SYLI), and decoding (PSWR), but it is negligible if measured after children have learned to read (SYL3).

(3) The relationship between syllabic awareness after learning to read (SYL3) and decoding (PSWR) is moderated by phonemic awareness (PHON) and intra-syllabic awareness (INTRA).

(4) Intra-syllabic awareness (INTRA) is related 10 decoding (PSWR) after children have leamed to read.
(5) Phonemic awareness (PHON) is related to decoding (PSWR) in children who have learned to read.

The final outcome measures were word reading (WR), pseudoword reading (PSWR), and reading comprehension (RC). The mediating variables were syllabic atwareness (SYL), intra-syllabic awareness (INTRA), phonemic awareness (PHON), and print awareness (PA).

\section{Results}

Table I displays the descriptive statistics of each variable included in the model.

The intercorrelations between all tasks are displayed in Table 2.

Table 1

Descriptive Statistics for Print Awareness and Phonological Awareness Tasks

\begin{tabular}{|c|c|c|c|}
\hline Tasks & Range & $M$ & $S D$ \\
\hline \multicolumn{4}{|l|}{ PRINT AWARENESS TASKS } \\
\hline 1. Print awareness (PA1) & $0-170$ & 95.4 & 63.3 \\
\hline 2. Print awareness (PA2) & $0-170$ & 117.0 & 58.4 \\
\hline 3. Print awareness (PA3) & $0-170$ & 148.0 & 34.2 \\
\hline \multicolumn{4}{|l|}{ PHONOLOGICAL AWARENESS TASKS } \\
\hline 1. Syllabic Awareness (SYLI) & $0-37$ & 12.4 & 9.7 \\
\hline 2. Syllabic Awareness (SYL2) & 0.37 & 15.4 & 10.1 \\
\hline 3. Syllabic Awareness (SYL3) & $0-37$ & 22.5 & 7.6 \\
\hline 4. Intrasyllabic awareness (INTRA) & 0.16 & 10.2 & 3.7 \\
\hline 5. Phonemic awareness (PHON) & $0-16$ & 8.4 & 3.6 \\
\hline \multicolumn{4}{|l|}{ READING TASKS } \\
\hline 1. Word reading (WR) & 0.40 & 13.4 & 10.2 \\
\hline 2. Pseudoword reading (PSWR) & $0-40$ & 19.8 & 12.6 \\
\hline 3. Reading comprehension (RC) & 0.10 & 5.6 & 2.8 \\
\hline
\end{tabular}

Table 2

Intercorrelations among all the Variables involved in the Model

\begin{tabular}{|c|c|c|c|c|c|c|c|c|c|c|c|}
\hline & PAl & PA2 & PA3 & SYL1 & SYL2 & SYL3 & INTRA & PHON & WR & PSWR & $R C$ \\
\hline PA 1 & - & & & & & & & & & & \\
\hline $\mathrm{PA} 2$ & $.82^{* * *}$ & - & & & & & & & & & \\
\hline $\mathrm{PA} 3$ & $.31 *$ & $.34 *$ & - & & & & & & & & \\
\hline SYLI & $.45^{* * *}$ & $.58 * *$ & .17 & - & & & & & & & \\
\hline SYL2 & $.57^{* *}$ & $.70^{* *}$ & .16 & $.73 * *$ & - & & & & & & \\
\hline SYL3 & .24 & $.32 *$ & $.42 \% *$ & $.39 *$ & $.31^{*}$ & - & & & & & \\
\hline INTRA & $.45^{* *}$ & $.45^{* * 4}$ & $.50^{* * *}$ & .29 & .29 & $.47^{* *}$ & - & & & & \\
\hline PHON & $.57^{* * *}$ & $.54 * *$ & $47^{* *}$ & $40^{* *}$ & $.42 * *$ & .29 & $.78 * *$ & - & & & \\
\hline WR & $-.35^{*}$ & $-.53 * *$ & $-.33 *$ & $-.50 \%$ & $-.68 * *$ & $-.33 * *$ & $-.33 * *$ & $-.49 * *$ & - & & \\
\hline PSWR & $-.41 *$ & $-.58^{* * *}$ & -.26 & $-.47^{* *}$ & $-.70^{* *}$ & -.24 & $-.47 * *$ & $-.59 * *$ & $.90 * *$ & - & \\
\hline $\mathrm{RC}$ & $.44 *$ & $.44 * *$ & $.43 * *$ & .31 & $39: *$ & $.39^{*}$ & $.52^{* *}$ & $.60^{* *}$ & $-.57^{\text {米米 }}$ & $-.53 * *$ & - \\
\hline
\end{tabular}

Note. $\mathrm{PA}=$ print awareness (measured at three different times); $\mathrm{SYL}=$ syllabic awareness (measured at three different tines); $\mathrm{INTRA}=$ intra-syllabic awareness; PHON = phonemic awareness; $W R=$ word reading; PSWR = pseudoword readjng; $R C=$ readjng comprehension. ${ }^{*} p<.05,{ }^{* *} p<.01$. 
We used the Lagrange Multiplier procedure (Bentler, 1989$, p. 68$)$ to test the hypothesis of the statistical need for restrictions in the model. The first type of restriction tested was to see whether the zero constraints that had been imposed were appropriate. When a constraint was inappropriate, the overall fit of the model improved substantially when the constraint was removed in a subsequent EQS run. That is, the type of restriction tested was to find out whether fixed parameters, such as "missing" paths or covariances that were set at zero in the model, were, in fact, nonzero in the population, and should therefore be treated as frec parameters and estimated in another run. As a result of this procedure, we generated Model 1, with an adequate goodness-of-fit level, normed fit index (NFI) $=.93$, root mean squared residuals $($ RMSR $)=.14$. However, this model improved when the influence of SYL1 on WR disappeared, and SYL1 influenced PSWR. Model 2, shown in Figure 2, was optimal in terms of statistical goodness of fit, NFI $=94$, RMSR $=$ .10 , and all of the cocfficients were statistically significant, $p<.05$. These values are shown in Table 3 .

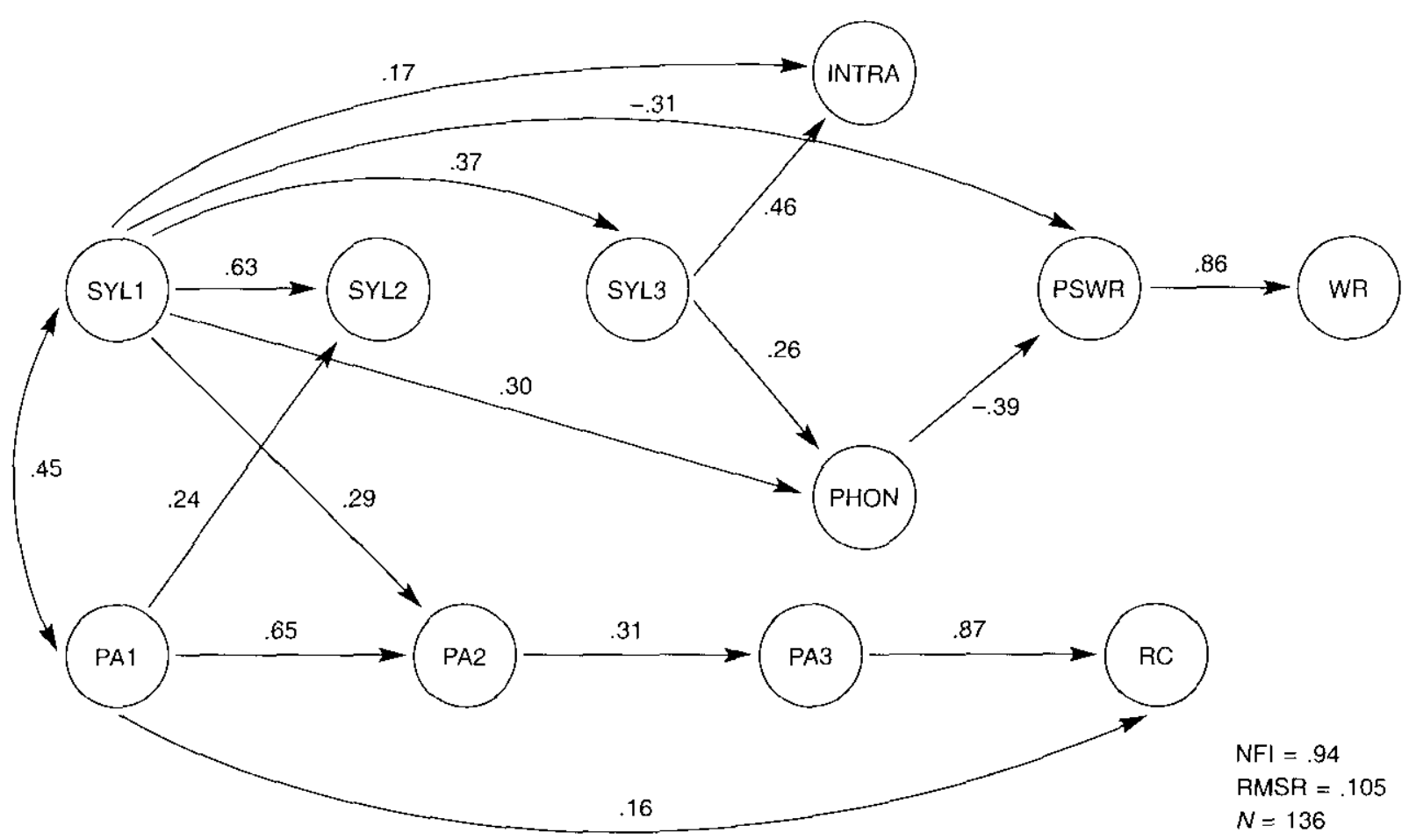

Figure 2. Model relating phonological awateness, print awareness, and reading performance in three different phases of reading acquisition, Arrows indicate the direction of the influence and the numbers represent the $B$ values from the path analysis. SYL $=$ syllabic awareness (measured at three different times: at the beginning of Kindergarten [SYL1], at the end of Kindergarten [SYL2], and at the end of first grade [SYL3]; INTRA = intra-syllabic awareness; PHON = phonemic awareness; PSWR = pseudoword reading; WR $=$ word reading; PA = print awareness (measured at three different times: at the beginning of Kindergarten [PA1], at the end of Kindergarten [PA2], and at the end of first gradc [PA3]); $\mathrm{RC}=$ reading comprehension.

Table 3

Structural Path Values and Goodness of Fit for Models Tested

\begin{tabular}{lcccc}
\hline & $x^{2}$ & $\mathrm{df}$ & RMSR & NFI \\
\hline Null model & $1,781.2$ & 55 & & $.93^{*}$ \\
Model 1 & 139.8 & 32 & .14 & $.94^{*}$ \\
Model 2 & 125.3 & 32 & .10 & $.92^{*}$ \\
\hline
\end{tabular}

Note, RMSR $=$ Root mean squared residuals; $\mathrm{NFI}=$ normed fit index; $\mathrm{NNFI}=$ nonnormed fit index.

$p<.05$. 
Table 3 shows that Model 2, with the same degree of freedom as Model 1, produces a decrease in the values of $\chi^{2}$ and of the mean residual of the variance and covariance matrix, as well as an increase in the goodness-of-fit indexes (NFI and NNFI, nonnormed fit index).

The word-reading variable (WR) was significantly related to pseudoword reading (PSWR). The coefficient value, $B=$ .86 , indicates that pseudoword reading predicts word reading. The pseudoword-reading variable (PSWR) was influenced somewhat by syllabic awareness (SYLI), $B=-.31$, and phoneme awareness (PHON), $B=-39$. The negative values indicate that errors in pseudoword reading tended to decrease proportionally to increases in syllabic and phonemic awareness. That is, pseudoword reading (or decoding) could be predicted by the syllabic awareness possessed by the children at the beginning of kindergarten (SYL1) but the relationship between SYLI and pscudoword reading was also moderated by phonemic awareness. No statistically significant path was found between intra-syllabic awareness (INTRA) and pseudoword reading; it was concluded that intra-syllabic awareness was not directly connected to pseudoword decoding.

As shown in Figure 2, the intra-syllabic awareness variable (INTRA), observed at the end of the first grade, was related to two of the measurements of syllabic awareness: SYL1 and SYL3, The children's syllabic awareness at the beginning of kindergarten (SYLI) was related to their intra-syllabic awareness (INTRA scores) in the first grade, $\beta=.17$, but their syllabic awareness after having received reading instruction, as rellected in SYL3 scores, revealed a stronger relationship with intra-syllabic awareness (INTRA), $B=.46$.

Phoneme awareness (PHON) also yielded a relationship with the same two measurements of syllabic awareness: SYLI, $B=.30$, and SYL3, $B=.26$. Therefore, it was concluded that phoneme awareness could be predicted from early syllabic awareness (SYL1). Further, as expected, SYL3 was influenced by SYL1, $B=.37$. That is, the children's syllabic awareness at the beginning of kindergatten (SYLI) produced a moderate relationship with their syllabic awareness at the end of the first grade, after having received reading instruction, reflected in SYL3. However, it is important to note that SYL3 following reading instruction bore no statistically significant relation to the children's syllabic awareness when they finished kindergarten (SY L2). It is as though the development of phonological ability changes drastically during the period in which the children receive formal reading instruction, so that syllabic awareness before reading instruction (SYL2) is not significantly related to syllabic awareness after reading instruction (SYL3). The lack of a statistically significant relationship between these variables suggests that reading instruction facilitates the development of phonological awareness because of the significant growth in syllabic awareness. However, before children learned to read, greater stability was observed. Syllabic awareness, as measured at the end of kindergarten (SYL2), was influenced by that already possessed at the begining of kindergarten (SYL1), $B=.63$. Also, SYL2 was also influenced by print awareness (PA1), $B=.24$. That is, the syllabic awareness (SYLl) and, to a lesser degree, print awareness (PAl) that the children possessed at the beginning of kindergarten were related to their syllabic awareness (SYL2) at the end of kindergarten.

Reading comprehension (RC) is explained in the model by print awareness at the end of first grade (PA3), $B=.87$, and ${ }_{+}$to a lesser extent, by print awareness at the beginning of kindergarten (PA1), $B=.16$. These results revealed the close relalionship between reading comprehension and print awareness; more precisely, the children's print awareness at the beginning of kindergarten (PAl) influenced their reading comprehension during the first grade, but their awareness in the first grade influenced reading comprehension even more so. With regard to print awareness, lower stability was observed during the period in which the children received literacy instruction (first grade), $B=.31$, than when they were in kindergarten, $B=.65$. Print awareness at the end of first grade (PA3) was influenced by print awareness at the end of kindergarten (PA2), $B=.31$, which, in turn, was influenced by print awareness at the begiming of kindergarten (PA 1), B $=.65$, and, to a lesser extent, by syllabic awarcness from the same period ( $S Y L 1$ ), $B=.29$. Moreover, print awareness at the beginning of the kindergarten (PA1) was also related to syllabic awareness during the kindergarten period (SYLI and SYL2), although, after this period, these two abilities were not related.

\section{Discussion}

The results of this study reveal the adequacy of the proposed conceptual model to explain the directivity between two metalinguistic abilities (i.e., phonological awareness and print awareness, PA) and two reading components: decoding and reading comprehension (RC). Cerlain components of the model had to be changed to make the model more coherent For example, the role of intra-syllabic awareness (INTRA) was not as great as we had assumed in the model.

It was confirmed that the levels of phonological awareness are related to the pseudoword and word reading, whereas print awareness is related to reading comprehension. These results support the fundamental idea that underlics the conceptual model proposed by Lundberg and Høien (1991) of the detcrmining factors involved in reading acquisition.

Confimation of the hypothesis that posited the existence of a relation between preliterate syllabic awareness and wordand pseudoword-reading is in accordance with the results of Spanish studies that showed that syllabic awareness was a good predictor of reading ability (e.g., Carrillo, 1993; Canrillo et al., 1992). We also confirmed the hypothesis that accounted for the change produced in the relation between syllabic awareness and decoding. once the child has received reading 
instruction. In this case, the relationship is indirect because, although syllabic awareness is related to phonemic awareness, only phonemic awareness has a direct relation with decoding. Consequently, the direct effect of phonemic awareness on reading means that it facilitates the application of the graphemephoneme conversion rules that require extensive control, because code-oriented instruction is often untelated to meaning.

The nil $\beta$ value, which reflects the degree of predictive relationship of the intra-syllabic awareness with reading, contradicts the hypothesis of a causal relation between these variables after reading instruction. This result is consistent with those studies in Spanish which revealed evidence that, at 6 years of age, the relationship between rhyme and reading tasks is low (Carrillo, 1994). Possibly, the relative incidence that each of the phonological awareness levels has on reading depends on the characteristics of each language, so that when the orthography is transparent, the decoding performance will be influenced to a greater extent by phonemic awareness. And when the language has deep orthography, it may be more influenced by intra-syllabic awareness (for a discussion, see Jiménez, 1997). For example, in the English language, units larger than phonemes present greater consistency in the correspondence between the written and the spoken forms (e.g., the sequence of the letters -ight are pronounced the same in light, fight, might etc.). Thus, children can read these words by making analogies about the sequence of letters that are represented in rime, as has been shown by Goswami and Bryant (1990). In the Spanish language, syllabic boundaries are clear, regularity in the orthographic correspondences is very high, and in the instances of complex correspondences (which do exist), the syllabic context determines the pronunciation (e.g., $c$ is pronounced as $/ k /$ when it is followed by the vowels $a, o$, or $u$, and as $/ t h /$ when followed by $e$ or i). Thus, phonemic awareness, as well as syllable awareness, can be very useful in the decoding of words. Therefore, once the children know the Spanish alphabetical code and possess phonemic awareness, it is not necessary to categorize words by their intra-syllabic components in order to be able to read. Thus, the relation between intra-syllabic awareness and decoding, at least after receiving reading instruction, may depend on the characteristics of the language in which one is learning to read.

Finally, the existence of a relationship between print awareness and reading comprehension was also confirmed in this study. Linguistic features of print were examined by the children before learning to read (Downing, 1979), and the essential feature is that "form" was the center of attention. Consequently, this ability proved to be a good predictor of future reading comprehension. We agree with Lundberg and Høien's claim (1995, p.15), which stated that the development of print awarencss is related to the amount of exposure to print and the opportunities to interact with texts under the supervision of encouraging and interested adults. By exposure to written language through story-reading, the child also gains familiarity with the particular syntactic organization and, more explicitly, with the elaborated and decontextualized nature of written discourse. This may be an important step in the acquisition of reading skills, as well as involving longterm impact on the cognitive system. In this context, automatization of control is also crucial for reading, because readers must not only coordinate attention to forms and the reconstruction of meanings, but must also process the forms sufficiently quickly and smoothly to allow space in the working memory to retain the evolving meanings (LaBerge \& Samuels, 1974; Perfetti \& Hogaboam, 1975).

Summing up, in our conceptual model, neither metalinguistic skills nor reading skills are considered to be the main determinants of reading comprehension. Rather, both are promoted by development of the same two underlying skill components, namely cognitive control and analyzed linguistic knowledge. Consequently, the relationship between them is a reflection of their shated cognitive basis. This approach also accounts for the reciprocal relationship, in which these research findings revealed that progress in each one of these domains, through instructional intervention, affects the progress of the other.

\section{References}

Ball, E.W. (1993). Phonological awareness: What's important and to whom? Reading and Writing: An Interdisciplinary Journal, $5,141-159$.

Bentler, P. (1989). EQS. V30 Software. Los Angeles, CA: BMDP. Bialystok, E., \& Bouchard, E. (1985). A metacognitive framework for the development of first and second language skills. In D.L. Forrest-Pressley, G.E. MacKinnon, \& T. Gary Waller (Eds.), Metacognition, cognition, and human performance (Vol. 1, pp. 207-252). London: Academic Press.

Bowey, J.A., \& Francis, J. (1991). Phonological analysis as a function of age and exposure to reading instruction. Applied Psycholinguistics, $12,91-121$.

Bradley, L., \& Bryant, P.E. (1985). Rhyme and reason in reading and spelling. I.A.R.L.D. Monographs 1. Ant Arbor, MI: University of Michigan Press.

Brown, A.L. (1980). Metacognitjve development and reading. In R.J. Spiro, B. Bruce. \& W.F. Brewer (Eds.), Theoretical issues in reading comprehension (pp. 453-481). Hillsdale, NJ: Erlbaum.

Bryant, P.E., MacLean, M., Bradley, L., \& Crossland, M. (1990). Rhyme, alliteration, phoneme detection, and learning to read. Development Psychology, 26, 1-10.

Byrne, B.M. (1994), Structural equation modeling with EQS and EQS/Windows. London: Sage.

Carrillo, M.S. (1993). Desarrollo de la conciencia fonológicosilábica y adquisición de la lectura. Unpublished doctoral dissertation, Murcia University, Spain.

Carrillo, M.S. (1994). Development of phonological awareness and reading acquisition. A study in Spanish Janguage. Reading and Writing: An Interdisciplinary Journal, 6, 279-298. 
Carrillo, M.S.. Romero, A., \& Sánchez-Meca, J. (1992). Development of phonological-syllabic awareness and beginning reading: A longitudinal study. Paper presented at the V European Conference on Developmental Psychology, Sevilla, Spain.

Downing, J. (1979). Reading and reasoming. Edinburgh, UK: Chambers.

Ehri, L.C., \& Wilce, L.S. (1980). The influence of orthography on readers' conceptualization of the phonemic structure of words. Applied Psycholinguistics, 1, 371-385.

Eliis. N., \& Large, B. (1987). The development of reading: As you seek, so shall you find. British Journal of Psychology, 78, 1-28.

Flavell, J.H. (1985). Cogntitive development. Englewood Cliffs, NJ: Prentice-Hall.

Flavell, J.H., \& Wellman. H.M. (1977). Metanemory. In R.V. Kail, Jr. \& W. Hagen (Eds.), Perspectives on the development of memory and cognition (pp. 3-33). Hillsdale, NJ: Erlbaum.

Francis, H. (1973). Children's expericnce of reading and notions of units in language. British Joumal of Educational Psychology, $43,17-23$.

Ganopole, S. (1987). Development of word consciousness prior to first grade. Joumal of Reading Behavior. 19, 415-436.

Gombert, J.E. (1992). Metalinguistic develomment. London: Harvester Wheatsheaf.

Goswami, U., \& Bryant, P. (1990). Phonological skills and leaming to read. Hillsdale, NJ: Erlbaum.

Hakes, D.T. (1980). The development of metalinguistic abilities in children. Berlin: Springer-Verlag.

Jiménez, J.E. (1997). A reading-level match study of phonemic processes underlying reading disabilities in a transparent orthography. Reading and Writing: An Interdisciplinary Joumal, 9, 23-40.

Jiménez, J.E., Guzmán, R., \& Artiles, C. (1997). Efectos de la frecuencia silábica posicional en el aprendizaje de la lectura. Cognitiva, $1,3-27$.

Jiménez, J.E.. Guzmán, R., \& Ortiz, M.R. (1991). Prueba de lectura. Unpublished Test, La Laguna University, Tenerife, Spain.

Jiménez, J.E., \& Ortiz, M.R. (1995). Prueba de Segmentación Lingüística. In Conciencia fonológica y aprendizaje de la lecrura (pp. 45-69). Madrid: Síntesis.

LaBerge, D., \& Samucls, S.J. (1974). Toward a theory of automatic information processing in reading. Cognitive Psychology, 6 . 293-323.

León, I. \& Hernández, J. (1998). Testing the role of atribution and appraisal in predicting own and other's emotions. Cognition and Emotion, 12, 27-43.

Lomax, R.G., \& McGee, L. (1987), Young children's concepts about princ and reading: Toward a model of word reading acquisition. Reading Research Quarterly, 22, 237-256.

Lorge, I., \& Thorndike, R.L. (1954). Lorge-Thomdike Intelligence Test. Boston, MA: Houghton Mifflin Company. (Sparish translation: Test de inteligencia. Madrid: Espasa-Calpe, 1976).

Lundberg, J., \& Høien, T. (1991). Initial enabling knowledge and skills in reading acquisition: Print awareness and phonological segmentation. In D. Sawycr \& B. Fox (Eds.), Phonological awareness in realing. The evolution of curent perspective (pp. 73-95). New York: Springer-Verlag.

Lundberg, I., \& Hoien . T. (1995). Levels of approaching reading and its difficulties. In B. Ericson \& J. Rönnberg (Eds.), Reading disability and its treatment (pp. 11-36). EMIR, Report N 2, Norrkoping: Eve Malmquist Institute for Reading, Linkoping University.

Lundberg. L., Otofsson, A., \& Wall. S. (1980), Reading and spelling skilts in the first school years predicted from phonemic awareness skills in kindergarten. Scandinatian Joumal of Psychology 21, 159-173.

Mickish, V. (1974). Children's perceptions of written word boundaries. Joumal of Reading Behavion; 6, 19-22.

Morais, J.. Cary, L., Alegría, J., \& Beterlson P. (1979). Does awareness of speech as a sequence of phones arise spontaneously? Cognirion, 7. 323-331.

Ortiz, M.R., \& Jiménez, J.E. (1993). Prueba de conocimientos sobre el lenguaje escrito. Madrid: TEA Ediciones.

Perfetti, C.A., \& Hogaboam, T. (1975). Relationshjp between single word decoding and reading comprehension skili. Joumal of Edrcational Psychology, 67, 461-469.

Read, C.. Zhang, Y. Nie, H., \& Ding. B. (1986). The ability to manipulate speech sounds depends on knowing alphabetic spelling. Cognition. 24, 31-34.

Share, D., Jorm, A., MacLeall, R., \& Mathews, R. (1984). Sourcos of individual differences in reading acquisition. Jownal of Edacaional Prychology, 76, 1309-1324.

Toro, J., \& Cervera. M. (1980). Test de análisis de lectura y escritura. Madrid: Pablo del Río.

Treman, R. (1991). Phonological awareness and its roles in learning to read and spell. In D.J. Sawyer \& B.J. Fox (Eds.), Phonological awareness in readisg. The evolution of carrent perspective (pp. 159-189). New York: Springer-Verlag.

Tunmer. W.E., \& Bowey. I.A. (1984). Metalinguistic awareness and reading acquisition. In W.E. Tunmer, C. Pratt, \& M.L. Herriman (Eds.), Metalinguistic awareness in children (pp. 144-168). New York: Springer-Verlag.

Tunmer, W.E. \& Herriman, M.L. (1984). The development of metalinguistic awareness: A conceptual overview. In W.E. Tunmer, C. Pratt, \& M.L. Herriman (Eds.), Metalinguistic: awdreness in children (pp. 12-35). New York: Springer-Verlag.

Tunmer, W.E., Herriman, M.L., \& Nesdale, A.R. (1988). Metalinguistic abilities and beginning reading. Reading Research Quarterly, 23, 134-158.

Wagner, R.K., \& Torgesen, J.K. (1987). The nature of phonological processing and its causal role in the acquisition of reading skill. Psuchological Bulletin, 101, 109-212.

Winmer, H., Landerl. K., Linortner, R., \& Hummer, P. (1991). The relationship of phonemic awareness to reading acquisition: More consequence than precondition but still important. Cognition, 40, 219-249.

Received April 28, 1998

Revision received March 10, 1999

Accepted July 1, 1999 